\title{
Epidemiology of malocclusion in children and adolescents: a critic review
}

\author{
Epidemiologia da má oclusão em crianças e adolescentes: uma revisão crítica
}

Fábio Silva de CARVALHO'

Cristiane Alves Paz de CARVALHO'

Arsenio SALES-PERES ${ }^{2}$

José Roberto de Magalhães BASTOS²

Sílvia Helena de Carvalho SALES-PERES²

\section{ABSTRACT}

\section{Objectives}

The aim of this literature review about malocclusion was to identify epidemiologic instruments which are being used in Public Health, as well as to bring information regarding the occlusal alterations more prevalent in children and adolescents.

\section{Methods}

Information presented in previous studies was reviewed, in articles published in period 1997-2007, considering the production registered in the following databases: Latin American and Caribbean Health Sciences, Scientific Electronic Library Online, International Database for Medical Literature and Brazilian Dentistry Bibliography.

\section{Results}

The total of 191 identified references, 170 had been eliminated after the implementation of the exclusion criteria and 21 articles met the proposed inclusion criteria and had served of base for this work. The use of different criteria made difficult the comparison of studies in literature and did not offer parameters that can guide the scientific evidences.

\section{Conclusion}

The most used epidemiologic indices were Dental Aesthetic Index and Index of Orthodontic Treatment Need and it was observed predominance of open bite in the deciduous dentition and crowding in the mixed and permanent dentitions.

Indexing terms: Epidemiology. Malocclusion. Public Health Dentistry.

\section{RESUMO}

\section{Objetivos}

Identificar os instrumentos epidemiológicos que estão sendo utilizados em Saúde Pública e trazer informações a respeito das alterações oclusais mais prevalentes em crianças e em adolescentes por meio de uma revisão da literatura sobre a má oclusão.

\section{Métodos}

Foram recuperadas informações apresentadas em trabalhos anteriores, incluídas em artigos publicados no período 1997-2007, considerando a produção registrada nas seguintes bases de dados bibliográficas: Literatura Latino-Americana e do Caribe em Ciências da Saúde, Scientific Electronic Library Online, Literatura Internacional em Ciências da Saúde e Bibliografia Brasileira de Odontologia.

\section{Resultados}

Do total de 191 referências identificadas, 170 foram eliminadas após a implementação dos critérios de exclusão e 21 artigos atenderam aos critérios de inclusão pré-estabelecidos, servindo, portanto, de base para este trabalho. A utilização de critérios distintos dificultou a comparação entre os estudos, não disponibilizando parâmetros que pudessem nortear as evidências científicas. Conclusão: Os índices epidemiológicos mais adotados foram o Índice de Estética Dental e o Índice de Necessidade de Tratamento Ortodôntico, sendo observado predomínio de mordida aberta anterior na dentição decídua e de apinhamento nas dentições mista e permanente.

Termos de indexação: Epidemiologia. Má oclusão. Odontologia em Saúde Pública.

\section{INTRODUCTION}

Notable transformations have been observed in epidemiological patterns of oral health diseases and disorders, which has led to different morbidities and conditions gaining importance in Public Health'. During this period, there has been growing interest in the development of researches about the etiology, methods of prevention and treatment of different oral pathologies and problems, such as malocclusions.

\footnotetext{
${ }^{1}$ Universidade Estadual do Sudoeste da Bahia, Departamento de Saúde. Jequié, BA, Brasil.

${ }^{2}$ Universidade de São Paulo, Faculdade de Odontologia, Departamento de Odontopediatria, Ortodontia e Saúde Coletiva. Al. Octávio Pinheiro Brisola, 9-75, 17012-901, Bauru, SP, Brasil. Correspondência para / Correspondence to: SHC PERES-SALES. E-mail: < shcperes@usp.br>.
} 
The high prevalence of malocclusion in the population has led the World Health Organization (WHO) to considering it the dental public health problem ranked in third place all over the world².

Malocclusion is an anomaly in the development of the dental arches, causing esthetic and/or functional problems, with the most common causes being osteogenic development, hereditariness, and acquired functional conditions. The above-mentioned conditions, such as pasty diets, mouth breathing and deleterious oral habits, especially pacifier sucking ${ }^{3}$, are among the main causes attributed to the development of malocclusion.

From the Public Health point of view, the purpose of knowledge of occlusal problems is to enable identification of individuals according to the priority of their needs. Therefore, clear definition of diagnostic criteria is important, in order to allow their application at epidemiological level and provide the planning of actions and obtainment of resources for orthodontic treatment ${ }^{1}$.

In the scientific literature, diverse clinical and epidemiological methods are found for the classification of occlusal problems, which differ with regard to objectives. The most widespread clinical method was developed by Angle. Other proposals, such as establishing the need for treatment have been developed to allow the classification of malocclusion according to the level of priority ${ }^{4}$. In the epidemiological field, we emphasize the Index of Orthodontic Treatment Need (IOTN) and Dental Esthetics Index (DAI), recommended by the WHO in $1997^{5}$.

The possibility of multiple occlusal alterations makes it difficult to have a simple classification that represents the epidemiological picture. Although there are a large number of studies in the literature about malocclusion, the different criteria for recording the occlusal condition limit comparisons among the results of different epidemiological surveys ${ }^{1,4}$.

There is a consensus in the literature and among professionals that malocclusion does not exclusively represent the characteristic of permanent dentition, and it is also present in the stages that precede occlusal maturity ${ }^{6}$.

The Ministry of Health, conducted an oral health epidemiological survey in Brazil in 2003, and identified the prevalence of malocclusions at the ages of 5,12 and 15 years, based on the criteria of the DAl index. At 5 years of age, the occurrence of malocclusions was $36.46 \%$; at 12 years it was $58.14 \%$ and at 15 years it was $53.23 \%$ of the population sample?
In this context, the aim of this study was to identify the epidemiological instruments that are being used in Public Health, and to bring information with respect to the most prevalent occlusal alterations in children and adolescents, by means of a review of the literature about malocclusion.

\section{METHODS}

The strategy of search for articles included researching the scientific literature using the "Biblioteca Virtual em Saúde" (BVS), by means of the following databases: Literatura Latino-Americana e do Caribe em Ciências da Saúde (Lilacs), Scientific Electronic Library Online (SciELO), Literatura Internacional em Ciências da Saúde (Medline) e Bibliografia Brasileira de Odontologia (BBO). A bibliographic search was made on the central theme of this study: the epidemiology of malocclusion and the criteria used in studies.

For this purposes, the references were located after an advanced search in BVS, by means of grouping the following descriptors: epidemiologia (epidemiology), maloclusão (malocclusion), dentição primária (primary dentition), dentição permanente (permanent dentition), dentição mista (mixed dentition), criança (child), adolescente (adolescent), odontologia em saúde pública (public health dentistry), Organização Mundial da Saúde (World Health Organization), Indices (indexes), located with the use of the Descriptors in Ciências da Saúde (DeCS) (Health Sciences (DeHSc). In addition the following limits were used: Aspects = epidemiology (/EP) AND Gender = male OR female AND Year of publication = 2007 OR 2006 OR 2005 OR 2004 OR 2003 OR 2002 OR 2001 OR 2000 OR 1998-1999 OR 19961997 AND Language $=$ Portuguese OR English .

All the productions in the form of articles, whose titles or abstracts mentioned the epidemiology of malocclusion in children or adolescents, in the period 19972007, were obtained in full and analyzed afterwards with regard to inclusion or exclusion. Studies with reference to clinical cases, radiographic comparative studies, or studies with specific populations (for example, individuals with cleftlip and palate), in spite of appearing in the search, were not considered eligible for inclusion in the present review. Furthermore, repetitions and some articles with limited availability in electronic databases were not considered.

Some bibliographic references of the studies located were also traced with the intention of locating other studies of potential interest for preparing this work, which eventually were not identified by the electronic search. 


\section{RESULTS}

According to the strategy established, the bibliographic search resulted in 191 references, distributed as follows: Lilacs (45), Medline (66), BBO (76) and SciELO (4). However, after implementation of the exclusion criteria, 170 references were eliminated: theses (43), books (2), theme not pertinent to the proposal (58), impossibility of obtaining the complete version of the article (10), in addition to the repetitions (57 articles catalogued in more than one database).

Therefore, the sample of this study consisted of 21 articles. These were obtain in full and then analyzed and categorized according to the year of publication, place where the research was conducted and period chosen for publication (Chart 1).

Chart 1. Characteristics of the studies on epidemiology of malocclusion, according to year, place and journal in which published.

\begin{tabular}{|c|c|c|c|}
\hline Authors & Year of Publication & City/State/Country: & Journal \\
\hline 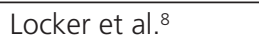 & 2007 & Toronto & Community Dent Oral Epidemiol \\
\hline Schwertner et al. ${ }^{9}$ & 2007 & Foz do Iguaçu, PR & RGO (Porto Alegre) \\
\hline Alves et al. ${ }^{10}$ & 2006 & Feira de Santana, BA & RGO (Porto Alegre) \\
\hline Gábris et al. ${ }^{11}$ & 2006 & Hungary & Eur J Orthod \\
\hline Oliveira et al. ${ }^{12}$ & 2006 & Rio de Janeiro, RJ & Rev CEFAC \\
\hline Souames et al. ${ }^{13}$ & 2006 & Val d'Oise, France & Eur J Orthod \\
\hline Thomaz \& Valença² & 2005 & São Luís, MA & RPG Rev Pós-Grad \\
\hline Marques et al. ${ }^{14}$ & 2005 & Belo Horizonte, MG & Cad Saúde Pública \\
\hline Frazão et al. ${ }^{15}$ & 2004 & São Paulo, SP & Rev Saúde Pública \\
\hline Cunha et al. ${ }^{4}$ & 2003 & Rio de Janeiro, RJ & Rev Dent Press Ortont Ortop Maxilar \\
\hline Iwasa et al. ${ }^{16}$ & 2003 & Region of Campinas, SP, Brazil. & RFO UPF \\
\hline Silva Filho et al. ${ }^{6}$ & 2003 & Bauru, SP & J Bras Odontopediatr Odontol Bebê \\
\hline Abdullah \& Rock ${ }^{17}$ & 2001 & Malaysia & Community Dent Oral Epidemiol \\
\hline Pires et al. ${ }^{5}$ & 2001 & Salvador, BA & Rev Bras Odontol \\
\hline Chi et al. ${ }^{18}$ & 2000 & New Zealand & Aust Orthod J \\
\hline Jonhson et al. ${ }^{19}$ & 2000 & New Zealand & Aust Orthod J \\
\hline Pereira et al. ${ }^{20}$ & 2000 & São Paulo, SP & Odontol USF \\
\hline Tomita et al. ${ }^{3}$ & 2000 & Bauru, SP & Pesq Odont Bras \\
\hline Alves et al. ${ }^{21}$ & 1999 & Rio de Janeiro, RJ & J Bras Odontopediatr Odontol Bebê \\
\hline Otuyemi et al. ${ }^{22}$ & 1999 & Nigeria & Int Dent J \\
\hline Tomita et al..$^{23}$ & 1998 & Bauru, SP & Rev Fac Odontol Bauru \\
\hline
\end{tabular}

In Chart 1, some of the general characteristics of the studies reviewed are described. The majority of the publications (57\%) were concentrated in the last five years $(12)^{2,4,6,8-16}$ and the remaining portion (9), in the period of 1998-20013,5,17-23.

There was diversity as regard the periodical published, however, the following periodicals: Revista Gaúcha de Odontologia, Jornal Brasileiro de Odontopediatria e Odontologia para Bebê, Community Dentistry and Oral Epidemiology, Australian Orthodontic Journal and European Journal of Orthodontics were those that allowed the largest number of articles to be located ( 2 in each) $)^{6,8-11,13,17-19,21}$. The other periodicals presented a uniform distribution with one article in each-25,12,14-16,20.

The type of study, criteria used for evaluating malocclusion, sample composition and manner in which it was selected, and prevalence of malocclusion in the studies are described in Table 1.
As regards design, 20 articles $2-6,8-17,19-23$ were characterized as being cross-sectional and 1 as longitudinal ${ }^{18}$. With regard to the criteria adopted in the studies, 12 articles adopted the DAl4-5,13,17,19-20, 7 articles selected used more than one index for evaluating malocclusion $4,5,8,15,17,19,20,6$ articles adopted the IOTN index $4,5,13,17,19,20,5$ articles related the prevalence of diverse

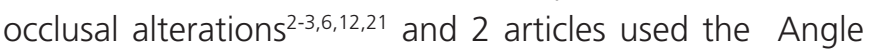
classification ${ }^{9,23}$.

With reference to the origin of the participating individuals, there was predominance of samples formed by children and adolescents located in schools, clinics or in the author's dental school of origin.

With regard to sample selection, it was randomly performed in 5 studies $2,4,6,9,14$, randomized in another $5^{11,17-}$ 19,22, by convenience in 7 articles 5,8,10,12-13,20-21, probabilistic in $2^{15-16}$ and 2 by conglomerate ${ }^{3,23}$. 
Table 1. Characteristics of studies on epidemiology of malocclusion according to the type of study, criteria evaluated, sample composition, sample selection, program and statistical test applied.

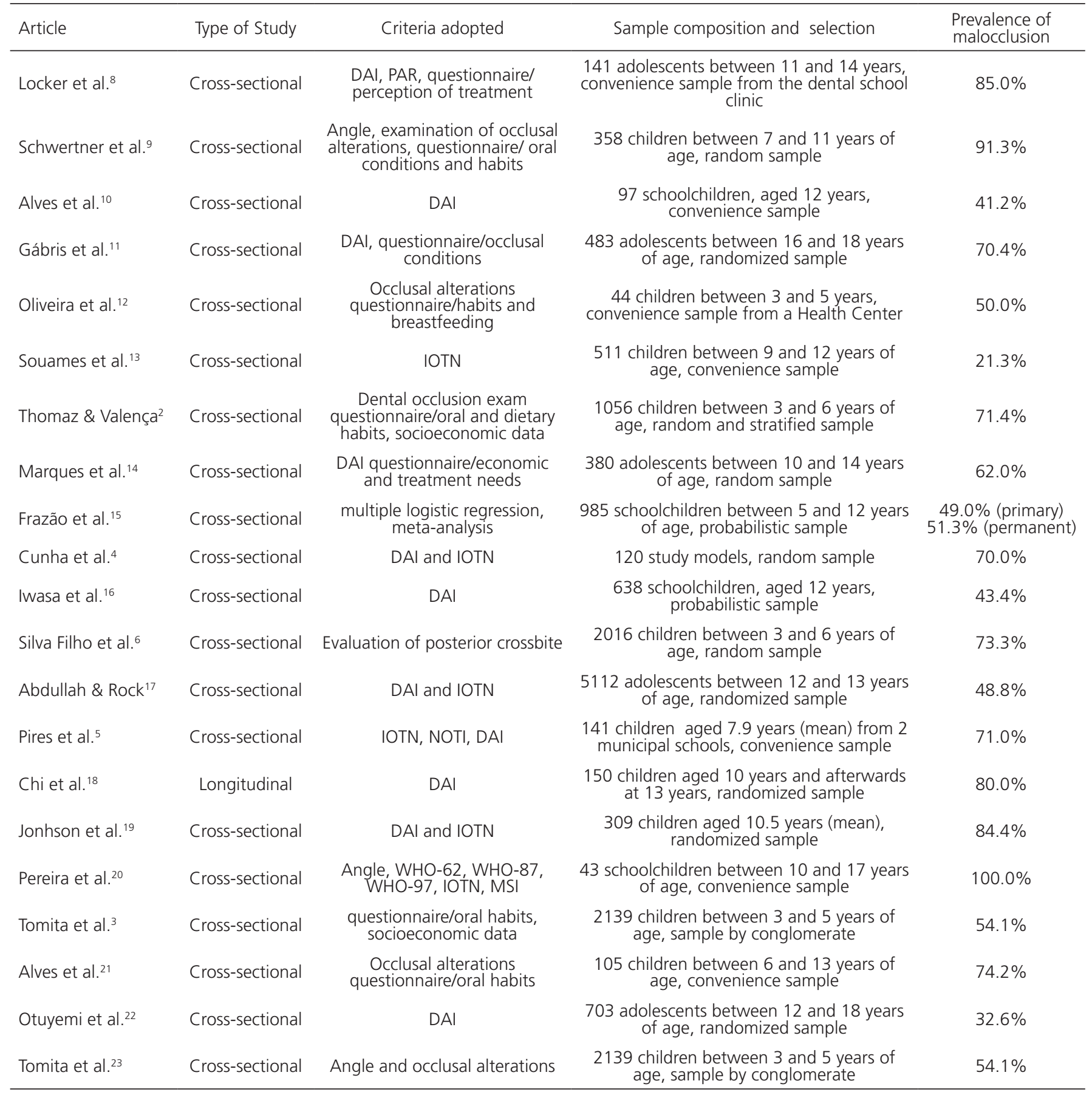

\section{DISCUSSION}

Malocclusion has been the object of study in diverse countries, due to its high prevalence in populations. Furthermore, the possibility of prevention and treatment is pointed out, in addition to the interference in the quality of life of the human being. For this reason, malocclusion may be considered a public health problem. Epidemiology may contribute to the elucidation of important questions with reference to malocclusion, such as the description of its distribution in the population, determination of the different alterations and factors associated with its development. 
The epidemiologic instruments adopted by researchers in their investigations has been rather varied. The IOTN and DAI were the most frequently adopted indices ${ }^{4-5,8,810-11,13-14,16-20,22}$, while some studies were based on the evaluation of a specific occlusal alteration $2-3,6,9,12,21,23$. The amplitude of occlusion conditions, allied to the diverse methods of measuring malocclusions has made it difficult to perform comparisons of the results of epidemiological studies.

The prevalence of malocclusion was considered high in various Brazilian municipalities, attaining values of over $70.0 \% \%^{2,5,6,9}$, as occurred in Hungary ${ }^{11}$. The lowest prevalence found was in France ${ }^{13}$ (21.3\%) and Nigeria ${ }^{22}$ (32.6\%).

Knowledge of the most prevalent alterations allows the adoption of public policies directed towards the needs of the population. Crowding ${ }^{4-5,9-10,13-14}$ was the alteration described most frequently in the articles analyzed, as presented by Schwertner et al., in 2007, who evaluated children in Foz do Iguaçu-PR ${ }^{9}$, Brazil, and found $65.5 \%$ of them with this problem. However, other investigations pointed out anterior open bite ${ }^{6,12,21}$, maxillary protrusion ${ }^{2}$, presence of diastemas ${ }^{23}$, alteration in molar relationship ${ }^{16}$ and spacing ${ }^{11}$.

With regard to the distribution of malocclusion according to gender, higher prevalence could be observed in the female gender ${ }^{2-3,6,23}$, although the study conducted in Campinas-SP16, Brazil, presented contradictory results.

Socioeconomic determinants were analyzed in some studies, and some associations were related to the occurrence of malocclusion, such as location and/or type of school, and children whose mothers were included in the work market. As regards the pre-school location, greater prevalence of alterations was found in children resident in the urban zone ${ }^{2}$, and as regard public or private type of school, greater alterations were found children at public schools ${ }^{6,16}$. In Bauru, SP, Brazil, higher prevalence of malocclusion was related in children whose mothers were included in the work market ${ }^{3}$, a fact that could be extrapolated, seeing that these mothers left their children at an early age, to go back to work, so that artificial bottlefeeding was introduced into the children's routine.

The presence of deleterious oral habits has been indicated as a strong risk factor for the development of malocclusions in individuals ${ }^{3}$. Among the most common habits related were pacifier sucking $2,5,6,12$, finger sucking $2,5,6,12,21$ and onicophagia (nail-biting) ${ }^{9}$. The presence of oral habits was more frequent in the female gender ${ }^{3,6}$, which appears to be related to the affective tie inherent to this gender. There was statistically significant association between malocclusion and deleterious oral habits, especially with pacifier and finger sucking 2,5,6,12,21. Therefore, the removal of these habits as early as possible must be recommended, so that this alteration does not attain bone levels.

With reference to breast feeding, greater prevalence of occlusal alterations was observed in children who were fed for a period shorter than six months $(71.4 \%)^{12}$, reiterating health promotion for pregnant women with a focus on the baby's oral health.

Studies that adopted the DAl index in the investigation of malocclusion found that approximately $10.0 \%$ of individuals were evaluated in the incapacitating category ${ }^{10,16,22}$, with the most significant value being related in Toronto, where $42.6 \%$ of the sample were found to have this degree of malocclusion ${ }^{8}$. Locker et al. ${ }^{8}$ justified this by bearing in mind that his was a convenience sample, using orthodontic patients.

In France, approximately $20.0 \%$ of children evaluated in accordance with the IOTN index presented treatment needs. The association between the occlusal component and esthetics in this index was shown to have high statistical significance in this study ${ }^{13}$. The perception of schoolchildren as regards their dental esthetics was shown to be coherent in view of the real orthodontic treatment needs.

Cunha et al. ${ }^{4}$ in their study evaluated the most frequent malocclusions and degree of treatment need by means of comparison between the DAI and IOTN indices. The data revealed that $72.5 \%$ and $74.2 \%$ of the cases presented severe orthodontic treatment need when using the DAI and IOTN, respectively. The same was found in New Zealand with similar results for the two indices ${ }^{19}$. In Malaysia, the two indices were also sued, with the IOTN being more efficient in the identification of adolescents with treatment needs ${ }^{17}$.

Schoolchildren and patients of a university in São Paulo, SP, Brazil, were evaluated with the aim of finding out about their occlusal conditions, using different epidemiological instruments in the exams. As instruments of measure, the following were used: Angle, WHO-62, WHO-87, WHO-97 (DAI), IOTN and MSI (Malocclusion Severity Index). The intraexaminer agreement was calculated at two distinct time intervals, with the greatest error being observed in the use of the DAI and MSI indices (85.71\% in both). With regard to orthodontic treatment needs, the MSI presented a statistically different proportion 
to that of all the other indices (97.57\%). There was also statistically significant difference between the IOTN and WHO-87 (67.44\% and 32.56\%) and between IOTN and DAl $(67.44 \%$ and $44.19 \%)$ indices $^{20}$. These results lead to the reflection that further longitudinal studies should be conducted, which are better able to demonstrate the way to measure malocclusion in public health.

There was high prevalence of malocclusion among children and adolescents, with the use of different criteria making comparisons among the studies difficult. There are no parameters available that could bring to light, knowledge of strong scientific evidence. The identification of occlusal conditions allows for planning and the adoption of public policies in oral health directed towards prevention and treatment.

\section{REFERENCES}

1. Peres KG, Tomita NE. Oclusopatias. In: Antunes JLF, Peres MA Epidemiologia da saúde bucal. Rio de Janeiro: Guanabara Koogan; 2006. p. 83-101.

2. Thomaz EBAF, Valença AMG. Prevalência de má-oclusão e fatores relacionados à sua ocorrência em pré-escolares da cidade de São Luís - MA - Brasil. RPG Rev Pos-Grad. 2005;12(2):212-21.

3. Tomita NE, Sheiham A, Bijella VT, Franco LJ. Relação entre determinantes socioeconômicos e hábitos bucais de risco para más-oclusões em pré-escolares. Pesqui Odontol Bras. 2000;14(2):169-75. doi: 10.1590/S1517-74912000000200013

4. Cunha ACPP, Miguel JA, Lima KC. Avaliação dos índices DAI e IOTN no diagnóstico de más oclusões e necessidade de tratamento ortodôntico. Rev Dent Press Ortodon Ortop Maxilar. 2003;8(1):51-8.

5. Pires DM, Rocha MCBS, Cangussu MCT. Prevalência de oclusopatias na dentadura mista em escolares - Salvador-BA. Rev Bras Odontol. 2001;58(6):414-7.

6. Silva Filho OG, Silva PRB, Rego MVNN, Capelozza Filho L. Epidemiologia da mordida cruzada posterior na dentadura decídua. JBP, J Bras Odontopediatr Odontol Bebê. 2003;6(29):61-8.

7. Brasil. Ministério da Saúde. Coordenação de Saúde Bucal da População Brasileira. Projeto SB Brasil 2003: resultados principais [citado 2009 Jan 15]. Disponível em: <http://dtr2004.saude.gov. br/dab/saudebucal/vigilancia.php >

8. Locker D, Jokovic A, Tompson B, Prakash P. Is the child perceptions questionnaire for 11-14 year olds sensitive to clinical and self-perceived variations in orthodontic status? Community Dent Oral Epidemiol. 2007;35(3):179-85. doi: 10.1111/j.16000528.2006.00324.x

9. Schwertner A, Nouer PRA, Garbui IU, Kuramae M. Prevalência de maloclusão em crianças entre 7 e 11 anos em Foz do Iguaçu, PR. RGO, Rev Gaúch Odontol. 2007:55(2):155-61.

\section{CONCLUSION}

The results allowed one to affirm that the epidemiological instruments most frequently adopted were the DAI and IOTN. There was predominance of anterior open bite in primary dentition, and in the mixed and permanent dentitions, there was the highest prevalence of crowding.

\section{Collaborators}

FS CARVALHO, CAP CARVALHO, A SALES-PERES, JRM BASTOS and SHC SALES-PERES participated in all stages of preparation of the article, right from conception through to the final writing of it.

10. Alves TDB, Gonçalves APR, Alves NA, Rios FC, Silva LBO Prevalência de oclusopatia em escolares de 12 anos de idade: estudo realizado em uma escola pública do município de Feira de Santana-BA. RGO, Rev Gaúch Odontol. 2006;54(3):269-73.

11. Gábris K, Márton S, Madléna M. Prevalence of malocclusions in Hungarian adolescents. Eur J Orthod. 2006; 28(5):467-70. doi: 10.1093/ejo/cjl027

12. Oliveira $A B$, Souza FP, Chiappetta ALML. Relação entre hábitos de sucção não-nutritiva, tipo de aleitamento e má oclusões em crianças com dentição decídua. Rev CEFAC. 2006;8(3):352-9.

13. Souames M, Bassigny F, Zenati N, Riordan PJ, Boy-Lefevre ML. Orthodontic treatment need in French schoolchildren: an epidemiological study using the index of orthodontic treatment need. Eur J Orthod. 2006;28(6):605-9. doi: 10.1093/ejo/cjl045

14. Marques LS, Barbosa CC, Ramos-Jorge ML, Pordeus IA, Paiva SM. Prevalência da maloclusão e necessidade de tratamento ortodôntico em escolares de 10 a 14 anos de idade em Belo Horizonte, Minas Gerais, Brasil: enfoque psicossocial. Cad Saúde Pública. 2005;21(4):1099-106. doi: 10.1590/S0102$311 \times 2005000400012$

15. Frazão P, Narvai PC, Latorre MRDO, Castellanos RA. Are severe occlusal problems more frequent in permanent than deciduous dentition? Rev Saúde Pública. 2004;38(2):247-54. doi: 10.1590/ S0034-89102004000200014

16. Iwasa EAP, Sousa MLR, Cypriano S. Prevalência de alterações oclusais de dentição permanente em escolares de 12 anos da região de Campinas, SP. RFO UPF. 2003;8(2):40-4.

17. Abdullah MS, Rock WP. Assessment of orthodontic treatment need in 5,112 Malaysian children using the IOTN and DAI indices. Community Dent Health. 2001;18(4):242-8.

18. Chi J, Johnson M, Harkness $M$. Age changes in orthodontic treatment need: a longitudinal study of 10 - and 13-year-old children, using the Dental Aesthetic Index. Aust Orthod J. 2000;16(3):150-6. 
19. Johnson $M$, Harkness $M$, Crowther $P$, Herbison $P$. A comparison of two methods of assessing orthodontic treatment need in the mixed dentition: DAI and IOTN. Aust Orthod J. 2000;16(2):82-7.

20. Pereira AC, Lascala CMM, Romero LG, Narvai PC. Avaliação de alguns instrumentos para detecção de má-oclusão dentária. Odontol USF. 2000;18(1):33-9.

21. Alves AC, Castro GF, Leite ICG, Bastos EPS. Sucção digital em crianças institucionalizadas: prevalência e relação com a maloclusão. JBP, J Bras Odontopediatr Odontol Bebê. 1999; 2(9):375-82

22. Otuyemi OD, Ogunyinka A, Dosumu O, Cons NC, Jenny J. Malocclusion and orthodontic treatment need of secondary school students in Nigeria according to the dental aesthetic index (DAI). Int Dent J. 1999;49(4):203-10.
23. Tomita NE, Bijella MFTB, Silva SMB, Bijella VT, Lopes ES, Novo NF, et al. Prevalência de má oclusäo em pré-escolares de Bauru-SPBrasil. Rev Fac Odontol Bauru. 1998;6(3):35-44.

24. Peres KG, Traebert ESA, Marcenes W. Diferenças entre autopercepção e critérios normativos na identificação das oclusopatias. Rev Saúde Pública. 2002; 36(2):230-6. doi: 10.1590/S0034-89102002000200016

Received on: 19/12/2011 Final version resubmitted on: 23/5/2009

Approved on: 8/6/2012 
